\title{
Determinación de mezclas de suelo estabilizado a partir de recursos de biomasa locales para mejorar la calidad de las viviendas construidas por la población del territorio de Uige, Angola Determination of stabilized soil mixtures based on local biomass resources used to improve the quality of housing built by the population in the territory of Uige, Angola
}

\author{
Jorge Rufino**, Iván Machado**, Yosvany Dias**
}

* Universidad Agostino Neto. ANGOLA

** Universidad Central Marta Abreu de las Villas. CUBA

Fecha de Recepción:13/03/2012

Fecha de Aceptación:27/07/2012

PAG $63-80$

\begin{abstract}
Resumen
El presente trabajo constituye una investigación que, partiendo de las condiciones socioculturales, económicas y climático-ambientales de Uige, tiene en cuenta los recursos materiales, técnicos y humanos disponibles, así como las prácticas y técnicas constructivas de las tipologías tradicionales de esa región angolana, para proponer soluciones a las grandes necesidades de vivienda en el territorio. Debido a diversos factores relacionados con la caracterización de la zona de estudio, el fondo habitacional construido con tierra o suelo no tiene la durabilidad suficiente, con lo que aumentan los costos debido al deterioro y fallos de las instalaciones. De aquí que se propone y aborda la presente investigación para lograr incrementar la estabilidad del suelo y con ello la mejora de sus características como material de construcción. En este sentido el trabajo estuvo centrado en dos aspectos, primero la caracterización de la zona de estudio y la identificación de las problemáticas que inciden sobre la calidad y durabilidad del fondo habitacional construido, en segundo lugar la determinación de la mezcla suelo - estabilizador adecuada a partir del reciclaje y transformación puzolánica de residuos agrícolas locales.
\end{abstract}

Palabras Clave: Suelo-estabilizado, transformación puzolánica

\section{Abstract}

The present investigation work, based on the socio-cultural, economic and climatic-environmental conditions of Uige Province, covers the available material, technique and human resources, as well constructive practices of traditional typologies of that region, in order to propose solutions for the great housing requirements in that territory. Due to diverse factors related to the characterization of this studied area, the housing stock built from earth or soil mixtures has a poor durability, thus increasing costs due to facilities' deterioration and failures. Therefore, the present research proposes a way to increase soil stabilization, so as to improve the construction material characteristics. In that sense, this research work was focused in two aspects. On one hand, it was focused on the characterization of the studied area and the identification of problems, which impact the quality and durability of the already built housing stock. On the other hand, it was focused on the determination of the adapted stabilized-soil mixture made by means of recycled materials and the pozzolanic transformation of local agricultural residues.

Keywords: Soil stabilization, pozzolanic transformation

\section{Introduction}

Several international research centers and organizations are presently dealing with the search of solutions to the overwhelming problems existing in the popular housing field, as well as the adequate production of construction material. The use of local material sources, including recycling practices as a way to prolong the life cycle including technological improvements on production processes, are some of the most significant measures that several national and international institutions are enhancing in this sense.

In this field, the fundamental role played by the Angola Estate consists of ensuring housing access to the most vulnerable families, by means of developers' diversification. Hence, institutions, laws, and financing supports have been created, which validate the importance of the use of appropriate and sustainable technologies within the framework of the prevailing situation in Angola's northern region. 
Presently, most of the population in Angola is extensively using soil mixtures for housing construction purposes. However, in spite of the historical ties to this housing technology, there is a total lack of knowledge on the appropriate construction methods (Redinha 1964; Universidade Católica 2011), which lead to the non-correct use of the natural resources existing in the territory, as well as to material waste and durability affectation. This is the reason why it is so convenient to study procedures and materials that may improve the housing construction process, in order to diminish the existing housing deficit in the country and in the region.

Consequently, the stabilized soil mixture becomes a material that may contribute to a better performance of the construction asset (De Sensi 2003). Anyway, the aspects related to material and housing costs must be taken into account (Viñuales 2007) (Saroza 2000). Therefore, the use of this local material is desired, being the biomass transformation a potential source of stabilizer element for soil construction.

According to Minke (Minke 2001), soil has been the predominant construction material in all kinds of hot, dry and temperate climates. Soil construction tracks date back to 9000 years ago. Presently, a third of world population lives on adobe housings and; in developing countries almost half of the inhabitants use the adobe for the construction of their housings (FAO 2010).

The proper soil mixture to be used as construction material, for a given specification, depends on its particular characteristics, especially on the type and content of clay, which acts as a binder to paste greater particles, in the same way cement acts in concrete (Minke 2001).

In some Central African countries such as Zambia, Congo, Zaire and South Africa, which have a similar cultural tradition on soil construction, technical normalization studies are being developed for the use of such material, in accordance with weather and geological characteristics existing in each one of them (ANGOLA 2008).

There are several techniques to work out an adobe mixture; most of them are ancestral ones, which have been kept with minor changes throughout time. Other techniques correspond to adaptations recently made, so as to improve the material properties. Frequently the structural failures on the constructed asset are strongly related to local traditions, the region climatology and the characteristics of the available soil (Pons 2001).

The soil has an important set of advantages as construction material, since it is a harmlessness material not containing toxic substances, it is recyclable, easy to obtain locally at low energetic expense (Viñuales 2007). In accordance with the reference bibliography, the author considers that soil qualities as construction material, can be improved by means of the addition of stabilizers coming from diverse sources. Besides the constructed structures deterioration and failures can be significantly reduced, if a set of technological recommendations are considered for this purpose. 
Therefore, it is suggested to support a proposal leading to improve technologies and construction local materials in the Uige region, by taking into consideration its requirements, constructive traditions, economy, human resources and materials availability.

Nowadays a huge amount of substances are used for soil stabilization. However, the author believes there is not a universal stabilizer, which could be used for all cases. Stabilization depends on the characteristics of the stabilizer agent and also on the soil properties. On the other hand, it is necessary to count with a stabilizer agent at reasonable cost.

In that sense, the use of soil stabilizers is proposed for the studied area by means of incinerated materials and biomass waste materials obtained locally. Resulting mixtures need to be characterized, by means of the determination of consistent properties and the proper low cost construction material condition.

\section{Development}

\subsection{Characterization of the studied area:}

Uige province is located at the north of Democratic Republic of Angola (Redinha 1964; Ladeiro 1994), which eastern boundary is the Congo Democratic Republic, the southern boundary is the Zaire Province, as shown on Figure 1. Uige is one of the most organized and best structured areas in the country from economical, political, social and cultural points of view. Its historical evolution dates back to the settlement of the Congo Kingdom. Portuguese colonists strongly influenced the local traditions, as well as the Bantu ethnic group that prevailed in the territory, which traditions are also significant.

The province is essentially based on agriculture, where several products are obtained, such as coffee, corn, almond, coconut, rice, beans, banana, pineapple, sweet potato, mango, papaya, cacao, tobacco, vegetal oil (Ladeiro 1994; ANGOLA 2008)

Soil exploitation; alternative materials, methods, formworks and tools employed for housing construction in any Angola's region will depend on the initiative and knowledge acquired for each case. Therefore, there is no uniformity of housing constructive characteristics in the country.

The characterization of the Uige Province was made in several stages, which are the selection of a method to characterize the study subject; the study of the evolution of traditional housing in Angola as well as its constructive traditions; and the social-demographic, social-cultural, climatic-environmental, technological and economical characterization.

A sample was selected to conduct this study, and several surveys were applied thus obtaining characteristics on the housing ownership, educational level of inhabitants, population ages per groups, labor condition, social-economic situation, housing features, water availability, electricity availability, etc. 
After analyzing the surveys conducted in the Uige Province, a group of descriptors and indicators was required to illustrate the area characterization and, also to support the rural housing construction project in this province.

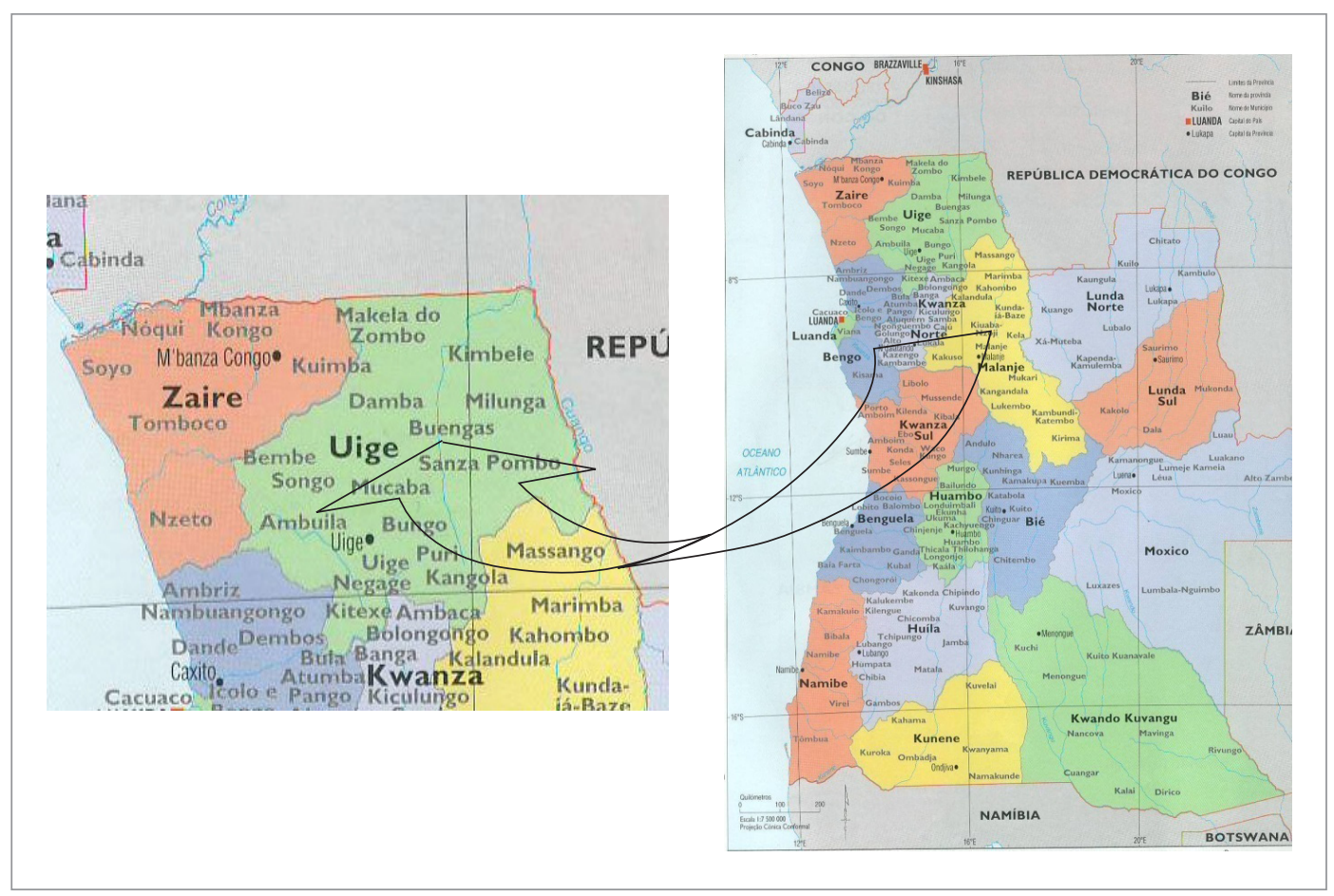

Figura 1. Ubicación geográfica de la región de estudio. Provincia Uige, Angola

Figure 1. Geographical Location of the region under study. Uige Province, Angola

Figure 2 presents a set of graphs showing the outcomes obtained for the most relevant descriptors and indicators under study. The graphs illustrates the characterization of the area under study, showing a relatively low level of rental housing (35\%), which might evidence a high level of population ownership and responsibility in regards to housing.

On the other hand, there is a relevant percentage of educated population, which might facilitate the explanation and understanding of graphs presentations and other types of information related to housing problematic issues. The low percentage of water availability throughout aqueducts and the poor access to electricity may reflect the economical conditions of this region.

There are a great number of housings inhabited by large families, who have a lower relative amount of square meters per inhabitant. Additionally, the housings' poor constructive conditions turn them into non-adequate buildings according to this present analysis. 
The construction of housing, their maintenance, durability and preservation in the Uige Province and, in Angola in general, become a very complex problem, which is within the framework of their inhabitants'social situation and deprivation conditions. Thus the solution depends on the development of a global community program, which today has serious shortages, such as the lack of projects involving nongovernmental organizations and government programs to fight the extreme poverty and unemployment (Redinha 1964; Carrera 1998; Lopes 2011).

There are insufficient networks of drinking water piping, drainage, sewage disposal conduits, poor commercial network infrastructure and non-effective government programs to enhance self-sustainable practices.

Similarly, the low educational level achieves a $16 \%$ of illiteracy rate, unemployment at a rate greater than $20 \%$, poor agricultural products trade, lack of highways and access roads and; almost a $38.7 \%$ of homeless people, which is quite significant for the purposes of this research.

The above factors notably affect this region's housing situation and, they also influence the methods and ways houses are built in this area. Houses are built by low economical resources people, who generally become temporary inhabitants and they do not transfer the available ancestral techniques from one generation to the next one, thus they only build temporary houses. Therefore, the complex housing condition cannot achieve a long-lasting solution.

Bantú Bakongo is the predominant ethnic group in Uige Province, which becomes an important social-cultural aspect of their way of living. Dweller's houses are usually small, having one or two bedrooms, the kitchen is generally placed outdoors and, due to space and comfort restrictions, they frequently use the house just to sleep and to shelter themselves from inclement weather.

In the same way, so as to understand the housing situation of the population living in the Uige Province, it is necessary to determine the environment-weather conditions and their effect on the housing construction and its status. The province is located in a region known as "torrid zone", which climate is predominately hot, tropical and wet, it has two well-defined seasons. Rainy season begins in September/October until May, being November and April the rainiest months. Dry season goes from June until August (ANGOLA 2008; Universidade Católica 2011), thus this season becomes the most appropriate for soil construction.

Precipitation averages reach almost $1500 \mathrm{~mm}$ per year. Practically there is no rain during dry season; however, there are high values of relative humidity. On the other hand, winds on permanent basis achieve speeds of almost $5.3 \mathrm{~km} / \mathrm{h}$, which constant impact generates wearing out on the walls surfaces, either on adobe's bricks or on the external plaster, due to the low density of the mortar not resisting corrosion of its particles. 
The main sources of housing wearing out correspond to rains and humidity, the lack of constructive reinforcements enduring natural phenomenon such as floods, landslides and ground caving due to geological instability, as well as maninduced factors (Redinha 1964; Higueras. 2003).

The construction sustainability status, under better conditions, will depend on the employment of minimum physical safety regulations, however, in Angola there are no soil construction regulations. In spite of that fact, in Angola the $63.5 \%$ of the population prefers to use this material for building their houses and they will continue to do so, mainly because of its low cost and its great availability for self-construction, because of thermal isolation properties and proper adaptation to the environment when the material is properly used.
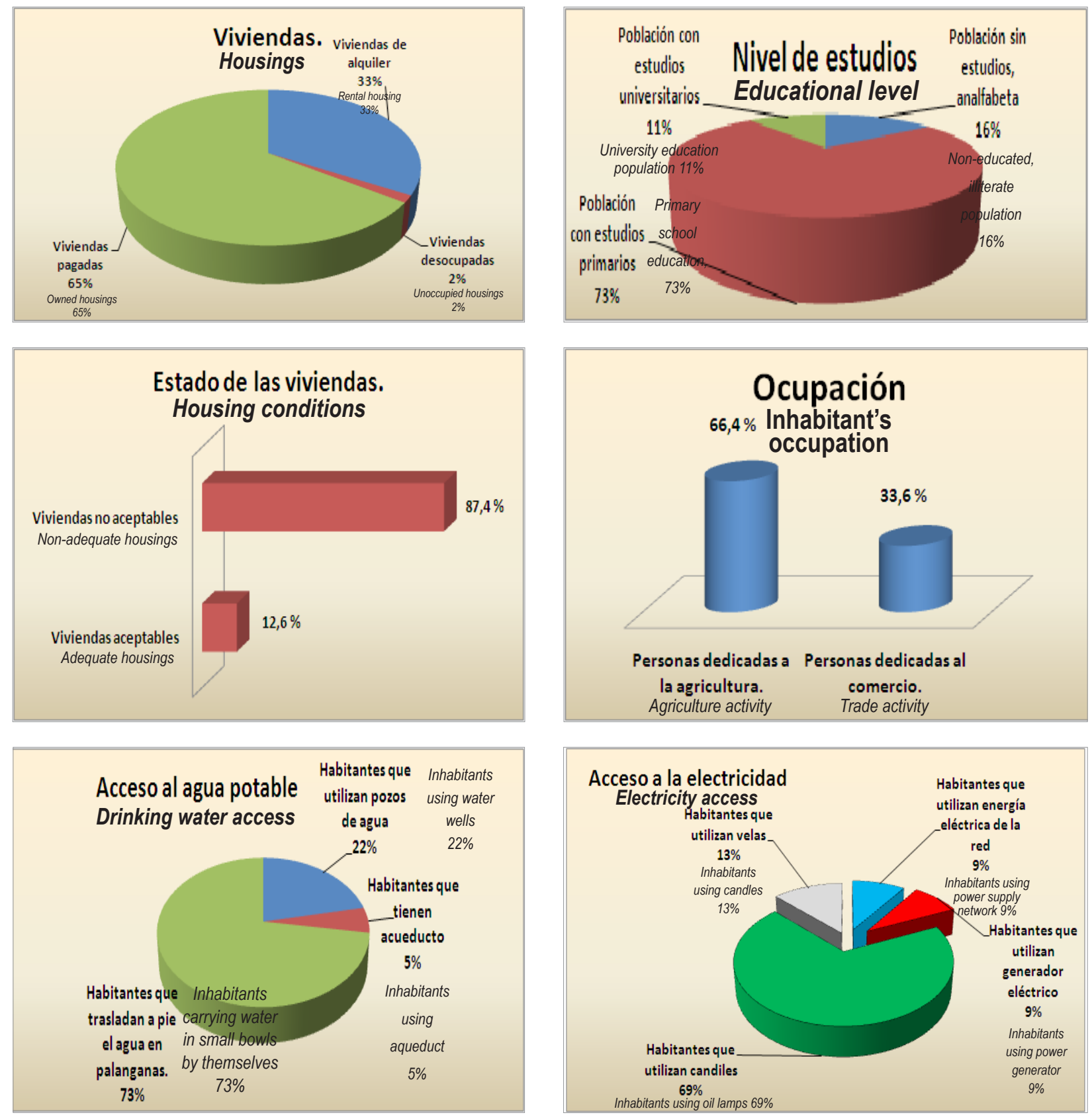

Figura 2. Ilustración gráfica de algunas de los descriptores y sus indicadores

Figure 2. some graphic illustrations of descriptors and their indicators 
2.1.1 Techological and typelogical housing characterization in the studied region

The housing characterization, per architectonic type, is based on the consideration of the spatial system provided by the productive activity developed by the inhabitant families.

The following constructive characteristics categorize Uige's housings.

Walls: They are elaborated from adobe and rammed earth.

Roofs: Deck is constructed from gable roof corrugated zinc supported on the side walls also having roof eaves. They also have guano roofs embedded into the walls.

Floors: They are elaborated from a stone and cement mixture.

However, constructive methods are not always adequate and, therefore, housings have a poor constructive durability and quality (Redinha 1964; Viñuales 2007). It is proven that the major problems are given by the affectations produced by humidity and the lack of knowledge on the preventive measures that could be foreseen, such as material quality improvement (soil stabilization), adequate foundations and protection by means of the use of wide roof eaves and walls plasters.

The set of recommendations contributing to housing durability, which are materialized throughout the constructive popular culture, are not always taken into account. Besides, the following constructive characteristics are considered as typical in the region.

Front walls are lengthened and oriented in east-west direction. The warm and humid environment requires some shade to AVOID solar radiation on east-west walls (front walls) and, also to take advantage of any air movement (crossed natural ventilation).

Shade elements mainly employed correspond to vertical or horizontal venetian blinds, and others of similar type. Rolled up railings are also required by front walls and outdoor corridors. Such elements provide protective shade to the adjacent rooms. Houses are normally made from adobe bricks, mud and straw, blocks and bricks.

Each house room has approximately the following areas: living-room $17 \mathrm{~m}^{2}$, kitchen $4 \mathrm{~m}^{2}, 2$ or 3 bedrooms $17 \mathrm{~m}^{2}$ each, rest room $3 \mathrm{~m}^{2}$, which is located outdoors.

Residential complexes are constantly expanding as the national birth rate is very high. Therefore, bedrooms are small and they do not provide the required comfort. The residential complex can be inhabited by 4 up to 8 persons. Several settlements are dispersed or concentrated in accordance with the family organization (Redinha 1964; Lamure 1980; Romero 1990; Sánchez 2007).

\subsection{Materials and methods}

\section{- Study of soil}

This research employs a portion of soil randomly selected from diverse locations close to the settlement, presently under construction, in the Angolan Uige Province. This soil portion is examined by means of a set of on-site feel-visual practices proposed by several authors (Morales 1993; Pons 2000; Minke 2001; Saroza 2006; Gomes 2009), 
showing properties which determine its suitability for housing construction from adobe bricks material.

Once this condition was fulfilled, a set of tests were developed in order to achieve its physical characteristics and its chemical composition. The soil was characterized finding that deposits have a plastic behavior, where light brown sandy clays are predominant, which have high carbonate percentages. Its main use is the local production of adobe bricks at small scale.

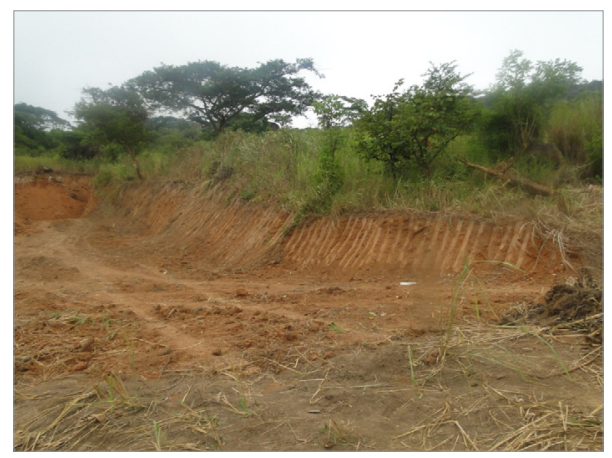

Figura 3. Cantera de extracción de suelo para la construcción de viviendas Figure 3. Soil exploitation quarry for housing Construction

The physical characteristics values of soil under study achieve the following average values: specific weight 2.69, liquid limit 44.04, plastic limit 22.52, plasticity index 21.52 and, clay content higher than $43.2 \%$.

\section{- Study of stabilizer agents. Sugarcane Bagasse Ashes (CBC) and African Palm Shells (CPA)}

Several materials were found in Uige territory that could be used as soil stabilizer agents. (See Table 1). Among them, sugarcane bagasse is a local low cost source widely available, as well as the African Palm Shells. Both of them were preliminarily selected as potential soil stabilizer agents, since these agricultural residues are not used for other purposes at this moment.

Tabla 1. Volumen de residuos agrícolas existentes en la región Table 1. Agricultural residues available in the region

\begin{tabular}{||l|l||}
\hline Residuos Agrícolas/ Agricultural residues & Existencia en Uige/ Availability in Uige \\
\hline Bagazo de caña de azúcar/Sugarcane bagasse & 936 mil toneladas/ thousand tons \\
\hline Cuesco de palma africana/ African palm shells & 589 mil toneladas/ thousand tons \\
\hline Cáscara de arroz/ Rice husk & No se produce suficiente/ Insufficient production \\
\hline Cascarilla de café/ Coffee husk & 25000 toneladas/tons \\
\hline Cocos/ Coconut & 80000 toneladas/tons \\
\hline
\end{tabular}


Sugarcane bagasse and African palm shell samples come from two huge plantations, from two small size sugar industries and several oil factories, which during 2011 produced 589 thousand tons of shells and, 936 thousand tons of sugarcane bagasse (Sosa 1994; Ferreira 2009; Alexander 2010).

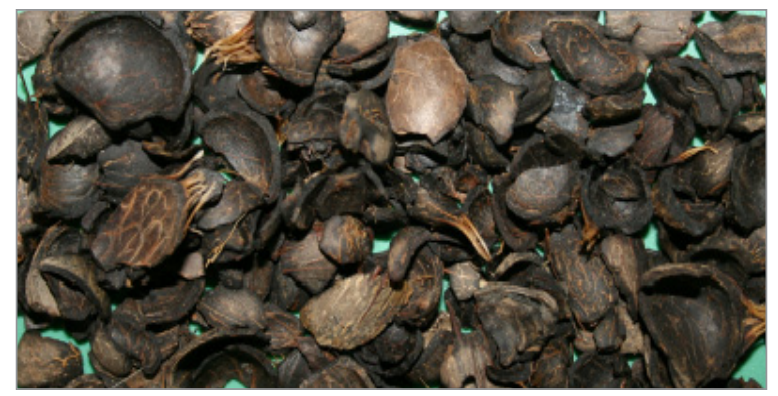

Figura 4. Cuesco de palma africana

Figure 4. African palm shell

Such agriculture residues were converted into ashes by means of combustion or incineration processes, at temperatures of 600,700 and $800^{\circ} \mathrm{C}$, during a period of 120 minutes. The temperature levels and time variables were provided in accordance with different authors (Sosa 1994; Ferreira 2009; Alexander 2010; Machado 2011).

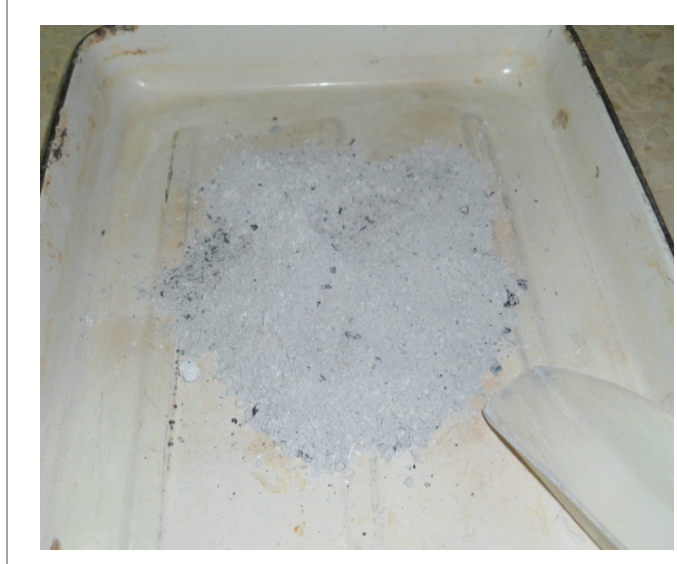

a)

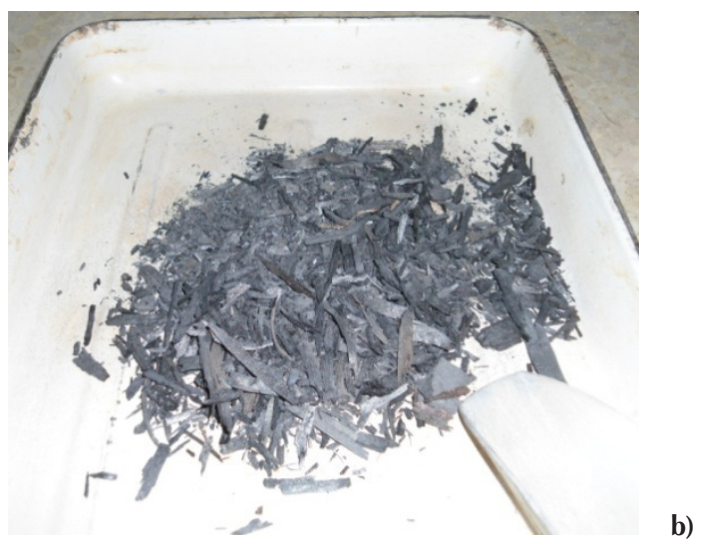

Figura 5. a) Ceniza de cuesco de palma africana, b) Ceniza de bagazo de caña

Figure 5. a) African Palm Shell ashes, b) sugarcane bagasse ashes

All obtained ashes were grinded by a Cole Casper 8955010 grinder cylinder, at a speed varying from 188 to $208 \mathrm{rad} /$ minute (30 and $33 \mathrm{rpm}$ ); and a total number of 500 turns were set. Once turns were completed, material was released from the cylinder and the sample was sieved by employing a sieve Nr. 200 (see Table 2).

Tabla 2. Distribución porcentual de la ceniza molida y tamizada

Table 2. Percentage distribution of grinded and sieved ash

\begin{tabular}{|c|c|c|c|c|c||}
\hline \multicolumn{4}{|c|}{ Ceniza de Cuesco de Palma Africana/ African Palm Shell ash } & \multicolumn{3}{c|}{ Ceniza de bagazo de caña/Sugarcane bagasse ash } \\
\hline Fracción/Fraction & Peso/Weight (g) & $\begin{array}{c}\text { Distribución/Distribution } \\
\%\end{array}$ & Fracción/Fraction & Peso/Weight ( g) & $\begin{array}{c}\text { Distribución/ } \\
\text { Distribution \% }\end{array}$ \\
\hline$>$ Tamiz/Sieve \#200 & 749 & 73.7 & $>$ Tamiz \# 200 & 765 & 72.9 \\
\hline$<$ Tamiz/Sieve \#200 & 267 & 26.2 & $<$ Tamiz \#200 & 256 & 25.9 \\
\hline
\end{tabular}


Ashes characterization tests were carried out at the Eduardo Torroja's Institute, Spain; at Cimangola Laboratory (concrete company in Angola) and at the laboratories of the National Applied Research Company (ENIA, Cuba).

\subsubsection{Ashes' chemical composition and pozzolanic reactivity \\ The following analyses were conducted: elemental analysis (percentages of carbon, hydrogen, nitrogen, sulfur and oxygen); immediate analysis (humidity as per ASTMD-3175-73, volatiles as per ASTMD-3175-77, ashes as per ASTM D-3174-73 and the content of carbon fixation). Additionally, calorific value was determined for a dynamic oxygen atmosphere $(50 \mathrm{ml} / \mathrm{min})$ considering temperatures ranging from 25 to $1,000^{\circ} \mathrm{C}$ at $10^{\circ} \mathrm{C} /$ min speed. The results of such analyses are shown on Table 3.}

Tabla 3. Análisis elemental e inmediato de los residuos agrícolas procedentes de Uige

Table 3. Elemental and Immediate Analyses on agricultural residues coming from Uige

\begin{tabular}{|l|l|l|l|l|l|l|l|l|l|}
\hline Muestras/ Samples & $\% \mathrm{H}$ & $\% \mathrm{Vv}$ & $\% \mathrm{O}$ & $\% \mathrm{Cf}$ & $\% \mathrm{C}(\mathrm{lhc})$ & $\% \mathrm{O}(\mathrm{lhc})$ & $\% \mathrm{H}(\mathrm{Ihc})$ & $\% \mathrm{~N}(\mathrm{lhc})$ & $\mathrm{CEC}$ \\
\hline BCA & 44,9 & 49,9 & 1,5 & 3,7 & 28 & 22 & 3,5 & 0,1 \\
\hline CPA & 11,2 & 48 & 1,4 & 39,4 & 40,2 & 40,5 & 5,7 & 11,5 \\
\hline
\end{tabular}

H: Humedad Vv: Volátiles A: Cenizas Cf: Carbono fijo C .Carbono O: Oxigeno H :Hidrog. N:Nitrog

H: Humidity; Vv: Volatiles; A: Ashes; Cf: Carbon fixation; C.Carbon; O: Oxygen; Hydrogen N:Nitrog

Leyenda: Ihc: libre de humedad y cenizas; CEC Poder calorifico(MJ/Kg.)

Legend: Ihc: humidity and ashes free; CEC calorific value (MJ/Kg.)

${ }^{1}$ Valor obtenido por calorimetría (Calorímetro Mettler-Toledo) Masa de trabajo. EN 14918

${ }^{1}$ Value obtained by means of calorimeter (Mettler-Toledo calorimeter) Work Mass. EN 14918

Fuente: Elaboración propia. Laboratorio IET. Madrid. España

Source: Self elaboration. IET Laboratory. Madrid, Spain.

For the thermal characteristics analysis on the selected biomasses, a thermogravimetry (TG) analyzer was employed, so as to determine the evolution of weight losses during combustion process and the final percentage of available ashes.

TG curves analysis shows a gradual weight loss modifying the curve slope in relation to the temperature. The process taking place in different stages or phases can be described as follows. At temperatures close to $130^{\circ} \mathrm{C}-140^{\circ} \mathrm{C}$, the curve has a small slope thus reflecting a lower weight loss, which is associated to the elimination of humidity contained by the sample. In the temperature range from 100 to $210^{\circ} \mathrm{C}$, humidity content and volatiles compounds are also removed, which are swept by the water vapor flow coming out from biomass during evaporation process.

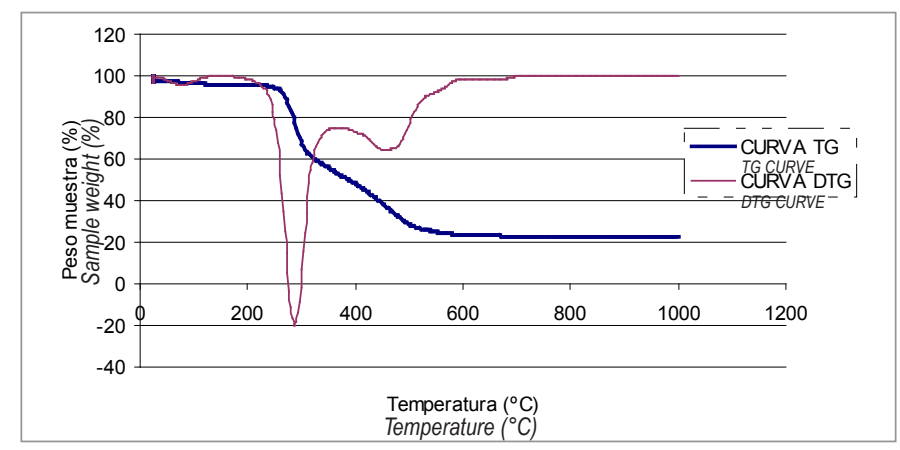

Figura 6. Variación del peso del CPA vs temperatura

Figure 6. CPA weight changes $\mathrm{v} / \mathrm{s}$ temperature 
Finally at temperatures higher than $210^{\circ} \mathrm{C}$, the biomass slope thermal-gavimetrical record significantly changes, thus indicating the beginning of the carbonization process provoked by the volatile compounds release. At temperature interval ranging from 220 to $660^{\circ} \mathrm{C}$, there is an increasing loss of biomass compounds, which are easily removed from the amorphous structure due to temperature effects. At temperatures higher than $600^{\circ} \mathrm{C}$, the weight loss mass is minimal, provided that in this stage the final volatiles-free product is obtained, which is the solid residue known as ash.

The obtained ashes amount, after proving its pozzolanic properties, can be used as construction material with similar characteristics to the fly ashes or other artificial pozzolans, which could noticeably improve the soil properties.

The pozzolanic reactivity study is conducted by using the residues of controlled combustion raw materials initially collected in the Uige City surroundings, in an electric muffle type $\mathrm{LH} 30 / 14$, at temperatures of 600,700 and $800{ }^{\circ} \mathrm{C}$.

Raw materials are placed in the furnace during a two-hour period, and then they are removed and cooled at environment temperature, in order to preserve morphological changes and transformations they may have suffered due to the thermal treatment effect.

The chemical composition of ashes presented on Table 4 show a potential pozzolanic behavior, in accordance with the main oxide content. There are no significant differences regarding diverse temperature levels, showing a noticeably low carbon content, which demonstrates this is an adequate biomass incineration process.

Pozzolanic reactivity is determined in accordance to the amount of lime reacting to the ash. This procedure is described by the European regulation EN - 450. Figure 7 shows the corresponding results. There is an upward tendency of pozzolanic reactivity throughout time, taking into account that the pozzolanic reaction takes places in a slower way than in the case of $\mathrm{CaO}$.

Such results are in the same line with the literature reporting adequate pozzolanic results for the sugarcane bagasse and straw incinerated at controlled temperatures in the range from 600 to $700{ }^{\circ} \mathrm{C}$ (Day 2000; Martirena J. F 2006). 
Tabla 4. Composición química. Cuesco de palma africana (CPA). Bagazo de caña de azúcar (BCA). (Temperatura de calcinación 600, $\left.700,800{ }^{\circ} \mathrm{C}\right)$ Table 4. Chemical composition. African palm shell (CPA). Sugarcane bagasse (BCA). (Incineration temperatures 600, 700, 800 ${ }^{\circ} \mathrm{C}$ )

\begin{tabular}{|l|c|c|l|l|l|l|l|l|}
\hline Comp. & CPA 6 & CPA 7 & CPA 8 & DS & BCA 6 & BCA 7 & BCA 8 & DS \\
\hline${ }^{*} \mathbf{S i ~}_{2}$ & 64,8 & 65,2 & 66,5 & 0,283 & 63,7 & 63,3 & 64,5 & 0,611 \\
\hline${ }^{*} \mathrm{Al}_{2} \mathbf{O}_{3}$ & 6,3 & 5,7 & 5,5 & 0,424 & 3,3 & 3,5 & 3,55 & 0,132 \\
\hline${ }^{*} \mathrm{Fe}_{2} \mathbf{O}_{3}$ & 2 & 2,5 & 2 & 0,252 & 3,8 & 4,2 & 3,2 & 0,503 \\
\hline $\mathbf{C a O}$ & 10,1 & 10,6 & 0,4 & 0,141 & 11,5 & 11,3 & 11,7 & 0,200 \\
\hline $\mathbf{K}_{\mathbf{2}} \mathbf{O}$ & 3,5 & 3,1 & 2,8 & 0,351 & 3,3 & 3,1 & 3,6 & 0,252 \\
\hline $\mathbf{M g O}$ & 3,55 & 3,4 & 3,3 & 0,126 & 3,6 & 3,1 & 3,3 & 0,252 \\
\hline $\mathbf{S O}_{3}$ & 1,2 & 1,35 & 1,3 & 0,076 & 1,5 & 1,8 & 1,7 & 0,153 \\
\hline $\mathbf{N a}$ & 0,6 & 0,52 & 0,49 & 0,057 & 0,45 & 0,4 & 0,38 & 0,036 \\
\hline $\mathbf{C a r b o n}$ & 1,35 & 1,3 & 1,2 & 0,076 & 1,6 & 1,46 & 1,4 & 0,103 \\
\hline $\mathbf{P P I}$ & 3,5 & 3,6 & 3,8 & 0,153 & 4,2 & 4,7 & 4,6 & 0,265 \\
\hline$\sum$ Óxidos $/$ Oxides $^{*}$ & 73,1 & 73,4 & 74,2 & 0,569 & 70,8 & 71 & 71,25 & 0,225 \\
\hline
\end{tabular}

The characterization results demonstrate that different obtained ash samples show significant differences, mainly in accordance with the incineration temperature. However, the $\mathrm{CaO}$ consumption analysis demonstrates that the samples reactivity is quite higher than the rate provided by the regulation $(150 \mathrm{~g} / \mathrm{g}$ ). The results shown on Figure 7.1 validate the use of African palm shells and sugarcane bagasse at the specified incineration temperatures. Similarly, the results of TG applied on palm shell ashes (3.68\% of weigh loss per ignition) and sugarcane bagasse ashes (4.5\% of weigh loss per ignition) indicate that material is properly incinerated.

The results of analisis developed on both ashes by means of X-ray diffraction (XRD) proved the presence of components such as feldspar and quartz. In accordance with the ASTMC 618-92 ${ }^{a}$ the ash employed is classified as a pozzolan type $F$ (MASSAZZA 1998; Minke 2001), as it contains more than $70 \%$ of main oxides $\mathrm{Si} \mathrm{O}_{2}+\mathrm{Fe}_{2} \mathrm{O}_{3}+\mathrm{Al}_{2} \mathrm{O}_{3}$ and; a loss per ignition lower than $6 \%$.

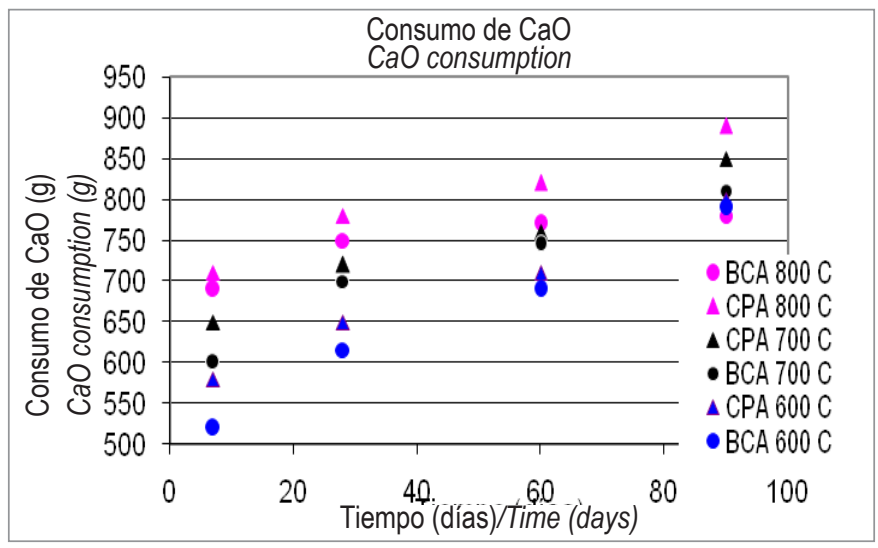

Figura 7. Determinación de la reactividad puzolánica de cenizas de CPA y BCA obtenidos en diferentes condiciones de incineración Figure 7. Determination of pozzolanic reactivity for CPA and BCA ashes, obtained from different incineration conditions 


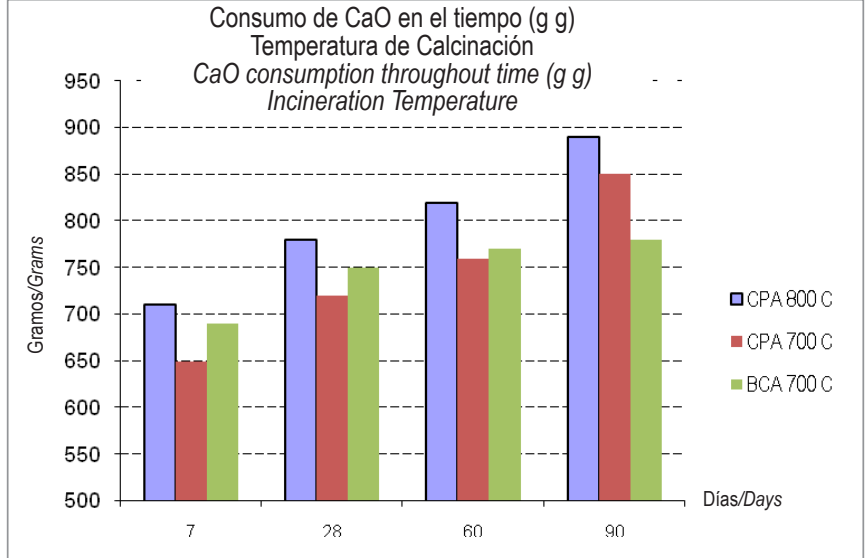

Figura 7.1. Condiciones de mayor consumo de $\mathrm{CaO}$

Figure 7.1. Conditions of higher consumption of $\mathrm{CaO}$

\subsubsection{Determination of the soil stabilizer mixture. Experimental Design:}

Reviewed bibliography refers to the studies conducted on sugarcane bagasse and African palm shell, which have been employed in boilers as combustion materials, to take advantage of their heating capacity. Under specific conditions, the ashes of different biomass sources acquire pozzolanic properties. Rice husks have been mechanically tested worldwide showing optimal results regarding compression resistance, by adding up to $10 \%$ of ashes in relation to the soil weight (Alexander, 2010; Machado, 2011; Alexandria, 2008 \# Bussoliti, 2009).

The factors considered for the determination of the soil stabilizer mixture, based on the soil characteristics of Uige region and on the proposed stabilizers, were delimited as follows. The ashes percentages of sugarcane bagasse and African palm shells were worked out at three levels: 2\%, 3\% and 5\%. Additionally, a pattern study was elaborated including $0 \%$ addition. Table 5 presents the matrix derivative of the experimental design, including a total of 18 mixtures differently evaluated.

It is important to highlight that the ashes showing the best pozzolanic properties, according to the incineration process, are tested. In this case the African palm shell ashes incinerated at $800{ }^{\circ} \mathrm{C}(\mathrm{CPA}-8)$ and sugarcane bagasse ashes incinerated at $700{ }^{\circ} \mathrm{C}(\mathrm{CBC}-7)$.

The evaluated response variables are: Compression Resistance and Density for the case of physical-mechanical properties. For durability study, capillary absorption tests were conducted.

As preliminary and essential action, it was necessary to elaborate different mixtures, in accordance with dosage purposes for each case. In order to achieve the raw material, water was poured into the soil and left standing still during 24 hours, so that the poured water was completely integrated to the clay component of the soil. 
Tabla 5. Diseño experimental

Table 5. Experimental design

\begin{tabular}{|c|c|c|c|c|}
\hline \multicolumn{5}{|c|}{$\begin{array}{l}\text { Estabilización con aglomerante CAL - PUZOLANA } \\
\text { Stabilization of soil using binder LIME - POZZOLAN }\end{array}$} \\
\hline \multicolumn{5}{|c|}{ Dosificación gravimétrica/ Gravimetrical Dosage } \\
\hline & \multicolumn{4}{|c|}{ Niveles/Levels } \\
\hline Variables & Patrón/ Pattern & Bajo/Low & Medio/Medium & Alto/ High \\
\hline Cal & 0 & $2 \%$ & $3 \%$ & $5 \%$ \\
\hline CPA - 8 & 0 & $4 \%$ & $5 \%$ & $6 \%$ \\
\hline CBA - 7 & 0 & $4 \%$ & $5 \%$ & $6 \%$ \\
\hline
\end{tabular}

Tabla 5.1. Matriz derivada del diseño de experimento

Table 5.1. Matrix derivative of the experimental design.

\begin{tabular}{|c|c|c|c|c|}
\hline $\begin{array}{l}\text { Descripción/ } \\
\text { Description }\end{array}$ & $\begin{array}{c}\text { Suelo/ } \\
\text { Soil }\end{array}$ & $\begin{array}{l}\text { Cal/ } \\
\text { Lime }\end{array}$ & CPA & CBC \\
\hline Mezcla/ Mixture 0 & $100 \%$ & & & \\
\hline Mezcla/ Mixture 1 & $98 \%$ & $2 \%$ & & \\
\hline Mezcla/ Mixture 2 & $97 \%$ & $3 \%$ & & \\
\hline Mezcla/ Mixture 3 & $95 \%$ & $5 \%$ & & \\
\hline Mezcla/ Mixture 4 & $96 \%$ & & $4 \%$ & \\
\hline Mezcla/ Mixture 5 & $95 \%$ & & $5 \%$ & \\
\hline Mezcla/ Mixture 6 & $94 \%$ & & $6 \%$ & \\
\hline Mezcla/ Mixture 7 & $96 \%$ & & & $4 \%$ \\
\hline Mezcla/ Mixture 8 & $95 \%$ & & & $5 \%$ \\
\hline Mezcla/ Mixture 9 & $94 \%$ & & & $6 \%$ \\
\hline Mezcla/ Mixture 10 & $94 \%$ & $2 \%$ & $4 \%$ & \\
\hline Mezcla/ Mixture 11 & $92 \%$ & $3 \%$ & $5 \%$ & \\
\hline Mezcla/ Mixture 12 & $89 \%$ & $5 \%$ & $6 \%$ & \\
\hline Mezcla/ Mixture 13 & $94 \%$ & $2 \%$ & & $4 \%$ \\
\hline Mezcla/ Mixture 14 & $92 \%$ & $3 \%$ & & $5 \%$ \\
\hline Mezcla/ Mixture 15 & $89 \%$ & $5 \%$ & & $6 \%$ \\
\hline Mezcla/ Mixture 16 & $90 \%$ & $2 \%$ & $4 \%$ & $4 \%$ \\
\hline Mezcla/ Mixture 17 & $87 \%$ & $3 \%$ & $5 \%$ & $5 \%$ \\
\hline Mezcla/ Mixture 18 & $82 \%$ & $5 \%$ & $6 \%$ & $6 \%$ \\
\hline
\end{tabular}

This preliminary mass was left standing still during the above mentioned period in a "humid chamber", which had a high relative humidity (approximately 95\%), so that the mass would not loose water during such period. Afterwards, this wet soil was amassed and the chosen stabilizer was added.

For the elaboration of specimens the following actions took place. Specimens were filled up layer per layer, downsizing the mixture until covering the whole specimen. Later the mixture was flashed and removed from the mould to proceed with specimens drying process, under shade during 21 days. 


\section{Analysis of results}

Once each series was worked out, in accordance with tests previously mentioned, an average was calculated for each one of them. Standard variation and variance were also calculated, among other statistical results. Trend analysis was then performed (Trend Graphs) for each response variable (average values of each result) and its corresponding combinations. At last, hypothetical tests were applied in order to evaluate the results significance.

\section{Compression resistance and Density}

The results obtained from compression resistance tests, for the case of specimens elaborated from mixtures 1 to 15 showed unfavorable results. They did not fulfill the minimum requisite of $1.00 \mathrm{Mpa}$ resistances, for adobe stabilized elements, as shown on Figure 8 (Saroza, 2005; Houben, 1994). Therefore, they were disregarded and the study only included mixtures showing a favorable behavior (Mixtures 0, 16, 17 and 18).
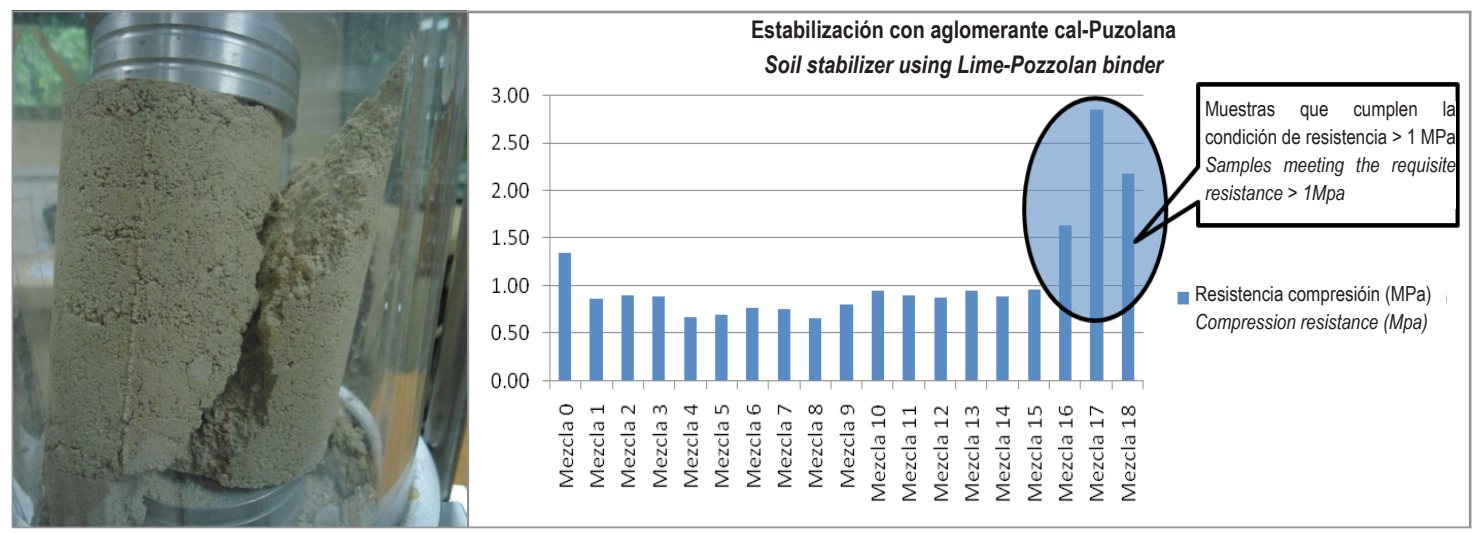

Figura 8. Resultados del ensayo a compresión

Figure 8. Results from compression test

From the Figure, please notice that the highest values were the ones obtained for compression resistance on the socalled mixture 17, thus proving that this trend is kept by the compression resistance values during the periods of 7, 21 and 28 days. Therefore, regarding such parameter, this mixture is to be considered so as to obtain the best practical application results. Then, it is proven that the mixture of $10 \%$ pozzolanic material ( $5 \% C B C+5 \% C P A)$ is the one providing best results.

Density determination results are presented by Figure 9, which are in line with the compression resistance test. The increase of density and compression resistance throughout time is explained by the function performed by the limepozzolan stabilizer binder, thus reinforcing the role played by clay agglutinating soil particles, which is precisely reflected by the density increase and the samples resistances. 


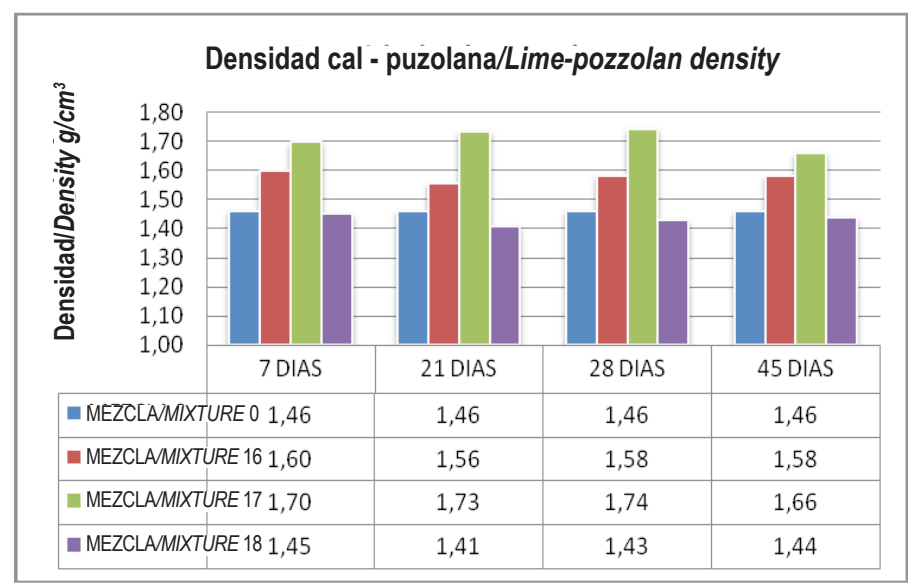

Figura 9. Gráfico de tendencia. Determinación de la densidad promedio de las muestras Figure 9. Trend graph. Determination of the samples average density

\section{Capillary absorption test}

Specimens elaborated as control sample (Sample 0) were disintegrated at the end of the test, due to the samples softening, as observed on Figure 10. It is concluded that deterioration suffered by Uige's houses can be provoked due to the lack of effective measures against humidity affectations, considering there is no tradition related to the use of soil stabilization in that region.

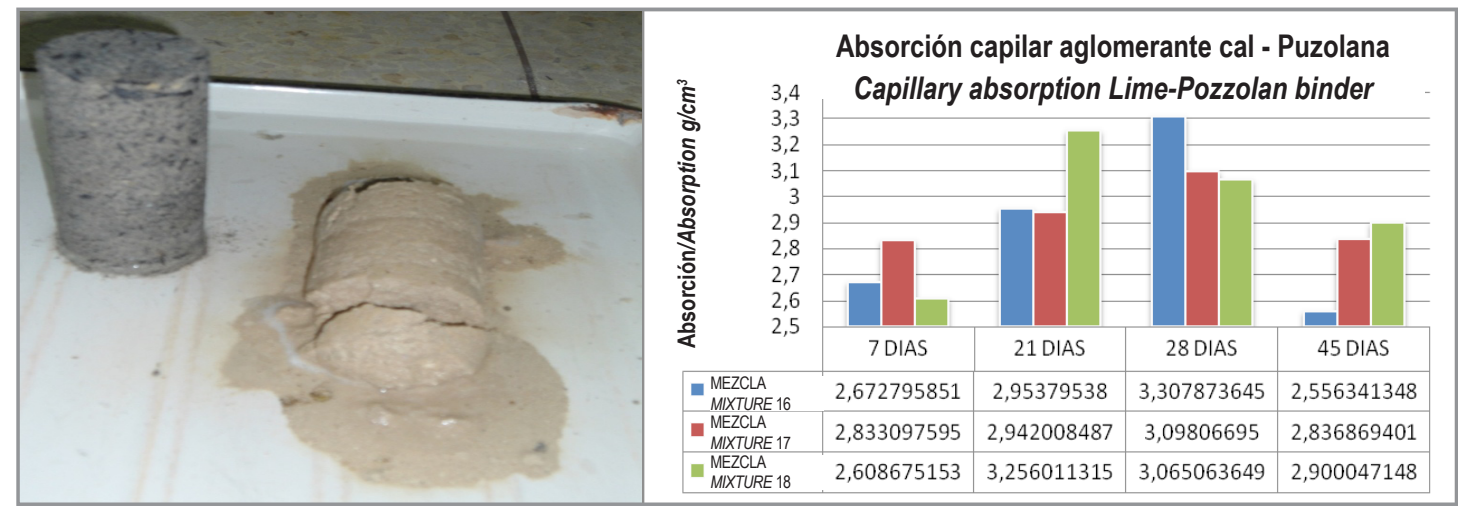

Figura 10. (Derecha) Muestra patrón sin adición de estabilizador totalmente afectada. (Izquierda) Resultados de resistencia a la adsorción capilar de las muestras de suelo estabilizado con las mezclas propuestas

Figure 10. (Right) Pattern sample without stabilizer addition, completely damaged. (Left) Capillary absorption results from stabilized soil samples, including proposed mixtures 


\section{Conclusions}

- The characterization of the area under study, considering diverse descriptors, proves the generalized use of soil as construction material. However, the non-acceptable conditions of most housings stock, reflects there is a material problem and constructive procedures are not adequate, mainly because of the prevailing economical situation.

- The incineration of local biomass sources, such as sugarcane bagasse and specially the African palm shell, which in turn allows recycling industrial waste materials, provides pozzolanic reactive components. They act together with lime on cementing particles that made up the mixtures soil-lime-pozzolan, thus improving the properties of this material.

- In the case of the soil under study, the mixture provided by the combination of pozzolan up to $10 \%(5 \% C P A+5 \% C B C)$ and lime $(3 \%)$ is the one that shows the best values of resistance, density and capillary absorption.

\section{Acknowlegements}

Authors wish to thank the following institutions for their contribution to this research:

ISPJAE. José A. Echeverría's Higher Institute. La Habana, Cuba.

IET. Eduardo Torrojas's Institute. Madrid, Spain.

ENIA. National Applied Research Company. La Habana, Cuba.

Ministry of Construction and Urban Planning. Luanda, Angola.

\section{Referencias/References}

Alexander G. W. Klose; Sonia Rincon (2010), Carbon activado de cueco de palma africana. Estudio de termogarvimetria y estrutura. Instituto de ingenieria termica, Universidad de Kassel, Alemania.

Angola A. G. D. (2008), Atlas geografico de angola

Carrera C. y. C. $\boldsymbol{d}$. a. (1998), "Trabajos prácticos de geografía humana". . Madrid, E.

Day R. M. J. F. y Middendorf B. (2000), Use of agricultural wastes for the production of building materials and energy. ENERGEX 2000, Proc. of the 8th International Energy Forum. . Las Vegas. USA.

De Sensi B. (2003), "'Terracruda, la diffussione dell'architectura di terra (soil, dissemination of earth arquitecture)"." 2006, from www. terracruda.com/architetturadiffusione.htm.

FAO (2010), "Organización de las Naciones Unidas para la Agricultura y la Alimentación." 2010, from http://www.fao.org/index_es.htm

Ferreira S. y Silva A. (2009), "Estudo das propriedades mecânicas de adobe com adição de fibras vegetais do coco verde. Encontro Nacional Sobre Aproveitamento de Resíduos na Construção - ENARC 2009. Feira de Santana, 08 a 10 jul..".

Gomes C., Cavalcante S., Farias T., Queiroz (2009), "Determinação da granulometria. Ensaios de Mecânica dos Solos. Fortaleza-CE, 2003, cap. 4, p. 15-24.".

Guinea M. (1987), "“La tierra, material resistente al agua", tomado de "La Tierra. Material de construcción"." Instituto Eduardo Torroja. Equipo VMBC. Madrid. España Monografía(No. 385/386): p25-30.

Higueras. A. M. (2003), "Teoría y método de la geografía. Introducción al análisis geográfico regional".

Ladeiro R. (1994), "Os ambós de Angola antes da independencia"." Universidade técnica de Lisboa, Instituto Superior de Ciencias Socias e Políticas, Lisboa: pp 45-53; 123-136.

Lamure C. (1980), Adaptación de la vivienda a la vida familiar. Barcelona

Lopes C., Candongueiros \& Kupapa (2011), Acumulacao, Risco e Sobrevivencia na economia informal em Angola. Portugal. 
Machado I. (2011), Transformacion Puzolanica del residuo de la combustion del conglomerado material arcilloso + Biomasa lignocelulosa. Departamento de Ingeniria Civil, Facultad de Construcciones. Santa Clara, Universidad Central Marta Abreu de las Villas.

Martirena J. F, M. B. D. R. M. G. R. P. M. L. B. S. (2006), "Rudimentary, low tech incinerators as a means to produce reactive pozzolan out of sugar cane straw." Cement and Concrete Research 36: 1056-1061

MASSAZZA, F. e. (1998), "Pozzolana and Pozzolanic Cements: Chapter 10. in." "Lea's Chemistry of Cement and Concrete".

Minke G. (2001), Manual de construcción para viviendas antisísmicas de tierra. U. d. Kasell. Alemania.

Morales R. y Rafael T. (1993), Manual para la contruccion de viviendas de Adobe. Lima, Peru.

NC 54190:00 (2000), "Oficina Nacional de Normalización, Standard test method for the evaluation of pozzolan admixtures by lime consumption. Cuba : s.n., 2000".

Pons G. (2000), "Adobe: La tierra como material de construcción. Tendencias recientes de la construcción con tierra"." 2010, from www. ecosur.org/index.php.

Pons G. (2001), "Comentarios sobre las casas de adobe"." from www.ecosur.org/index.php.

Redinha (1964), A habitacao tradicional em Angola. Edicao do Centro de informacao e Turismo de Angola.

Romero M. (1990), "Tradiciones de Arquitectura de tierra en Nuevo México". ." 2007, from www.aragob.es/edycot/patrimonio/etno/ pastoril/portada.

Sánchez C. (2007), "La arquitectura de tierra en Colombia, procesos y culturas constructivas"." Revista de estudios sobre patrimonio cultural - Journal of Cultural Heritage Studies 20(Nº. 2): pags. 242-255.

Saroza B. (2000), "Experiencias de la estabilización del adobe con cal, asfalto, cemento y miel de caña". 4to. Simposio Internacional de Est. Geotecnia y Mat. Const. Santa Clara, Cuba.

Saroza B. y Rodríguez M. (2006), "Identificación de la composición óptima del adobe como material de construcción de una escuela en Cuba"." Revista Materiales de construcción. Instituto Eduardo Torroja, Madrid, España 56, No 282.

Sosa M. (1994), "Utilización de materias primas vegetales para la producción de materiales de construcción: análisis críticos. Trabajo especial (agregado), Facultad de Venezuela, p.11.".

Universidade Católica A. (2011), "Relatório social de Angola"." Centro de Estudos e Investigacao Científica.

Viñuales G. (2007), "Tecnología y construcción con tierra". ." Journal of Cultural Heritage Studies №. 2,: pags. $220-231$. 